\title{
Target species selection criteria for risk assessment based exemptions of ballast water
} management requirements

Gollasch, Stephan; David, Matej; Broeg, Katja; Heitmüller, Susanne; Karjalainen, Miina; Lehtiniemi, Maiju; Normant-Saremba, Monika; Ojaveer, Henn; Olenin, Sergej; Ruiz, Marta

Total number of authors:

13

Published in:

Ocean \& Coastal Management

Link to article, DOI:

10.1016/j.ocecoaman.2019.105021

Publication date:

2020

Document Version

Peer reviewed version

Link back to DTU Orbit

Citation (APA):

Gollasch, S., David, M., Broeg, K., Heitmüller, S., Karjalainen, M., Lehtiniemi, M., Normant-Saremba, M., Ojaveer, H., Olenin, S., Ruiz, M., Helavuori, M., Sala-Pérez, M., \& Strake, S. (2020). Target species selection criteria for risk assessment based exemptions of ballast water management requirements. Ocean \& Coastal Management, 183, [105021]. https://doi.org/10.1016/j.ocecoaman.2019.105021

\section{General rights}

Copyright and moral rights for the publications made accessible in the public portal are retained by the authors and/or other copyright owners and it is a condition of accessing publications that users recognise and abide by the legal requirements associated with these rights.

- Users may download and print one copy of any publication from the public portal for the purpose of private study or research.

- You may not further distribute the material or use it for any profit-making activity or commercial gain

- You may freely distribute the URL identifying the publication in the public portal 
Target species selection criteria for risk assessment based exemptions of ballast water management requirements

Stephan Gollasch ${ }^{\mathrm{a}, *}$, Matej David ${ }^{\mathrm{b}}$, Katja Broeg ${ }^{\mathrm{c}}$, Susanne Heitmüller ${ }^{\mathrm{c}}$, Miina Karjalainen ${ }^{\mathrm{d}}$, Maiju Lehtiniemi ${ }^{\mathrm{e}}$, Monika Normant-Saremba ${ }^{\mathrm{f}}$, Henn Ojaveer $^{\mathrm{g}}$, Sergej Olenin ${ }^{\mathrm{h}}$, Marta Ruiz ${ }^{\mathrm{i}}$, Markus Helavuori ${ }^{\mathrm{i}}$, Manuel Sala-Pérez ${ }^{\mathrm{i}}$, Solvita Strake ${ }^{\mathrm{j}}$

sgollasch@gmx.net, matej.david@siol.net,katja.broeg@bsh.de, susanne.heitmueller@bsh.de, miina.karjalainen@merikotka.fi, maiju.lehtiniemi@ymparisto.fi, monika.normant@ug.edu.pl, henn.ojaveer@ut.ee, sergejolenin.so@gmail.com, marta.ruiz@helcom.fi, markus.helavuori@helcom.fi, manuel.salaperez@helcom.fi,solvita.strake@lhei.lv

${ }^{\mathrm{a}}$ GoConsult

Grosse Brunnenstrasse 61, 22763 Hamburg, Germany

*Corresponding author.

E-mail address: sgollasch@gmx.net (S. Gollasch).

${ }^{\mathrm{b}}$ Dr. Matej David Consult d.o.o.

Korte 13 e, 6310 Izola, Slovenia (matej.david@siol.net)

${ }^{\mathrm{c}}$ Bundesamt für Seeschifffahrt und Hydrographie

Bernhard-Nocht-Straße 78, 20359 Hamburg, Germany (katja.broeg@bsh.de, susanne.heitmueller@bsh.de)

${ }^{\mathrm{d}}$ Kotka Maritime Research Association

Keskuskatu 10, 48100 Kotka, Finland (miina.karjalainen@merikotka.fi)

${ }^{\mathrm{e}}$ Marine Research Centre, Finnish Environment Institute

Latokartanonkaari 11, 00790 Helsinki, Finland (maiju.lehtiniemi@ymparisto.fi)

${ }^{\mathrm{f}}$ Department of Experimental Ecology of Marine Organisms, Institute of Oceanography, University of Gdańsk

Al. Marszałka J. Piłsudskiego 46, 81-378 Gdynia, Poland (monika.normant@ug.edu.pl)

g University of Tartu

Ringi 35, 80012 Pärnu, Estonia (henn.ojaveer@ut.ee)

and

National Institute of Aquatic Resources, Technical University of Denmark, Kemitorvet

Building 201, 2800 Kgs. Lyngby, Denmark

${ }^{\mathrm{h}}$ Marine Research Institute, Klaipeda University

Universiteto al. 17, 92294, Klaipėda, Lithuania

(sergejolenin.so@gmail.com)

${ }^{\text {i }}$ Baltic Marine Environment Protection Commission 
Katajanokanlaituri 6 B, 00160 Helsinki, Finland

(marta.ruiz@helcom.fi, markus.helavuori@helcom.fi, manuel.salaperez@helcom.fi)

${ }^{\mathrm{j}}$ Latvian Institute of Aquatic Ecology

Voleru str. 4, 1007, Riga, Latvia

(solvita.strake@lhei.lv)

Declarations of interest: none.

\title{
Target species selection criteria for risk assessment based exemptions of ballast water management requirements
}

\begin{abstract}
The Ballast Water Management Convention adopted at the International Maritime Organization (IMO) allows exemptions from ballast water management requirements. These exemptions may be granted when a risk assessment results in an acceptable low risk scenario. IMO has adopted a guideline describing different risk assessment approaches (G7 Guidelines, 2017). One approach is a species-specific risk assessment in which so called target species (TS) become important. TS are species that meet specific criteria indicating that they may impair or damage the environment, human health, property or resources and they are defined for a specific port, State or biogeographic region. The guidelines continue to describe general TS selection criteria, which include the species relationship with ballast water as a transport vector, their impact type and severeness, evidence of prior introduction(s), and its current distribution. However, the G7 Guidelines lack details how these criteria are to be defined. This paper presents the TS selection criteria developed during the EU-Interreg Baltic Sea Region COMPLETE project (Completing Management Options in the Baltic Sea Region to Reduce Risk of Invasive Species Introduction by Shipping), including explanations on what ballast water relationship means, which impact threshold is eligible to identify a TS, as well as
\end{abstract}


why prior introductions and the current species distribution are relevant in that context. It was concluded that TS lists need to be regularly reviewed and that the described TS selection criteria may be also adopted elsewhere when planning species-specific risk assessments for exemptions from ballast water management requirements. 


\section{Introduction ${ }^{1}$}

IMO developed a detailed RA to evaluate the risk of species transferred by ballast water in the G7 Guidelines (IMO, 2007a) and these guidelines were recently updated (IMO, 2017). Two fundamentally different RA approaches were developed under the IMO BWM Convention, i.e., the selective and the blanket approach (IMO, 2017). This was done to avoid placing a burden, in form of a "one suits all” BWM requirement, on all ships. Such a blanket approach would result, in low risk cases, in unnecessary BWM requirements, which would trigger unnecessary costs and chemical burden for the aquatic environment caused by ballast water treatment. In contrast, the selective approach means that BWM measures are required according to the different risk levels posed by the ballast water intended for discharge. The RA result may trigger that ships are exempted from BWM requirements if the ballast water discharge risk level is acceptable (David et al., 2013, 2015; Olenin et al., 2016; David and Gollasch, in press). On the opposite, i.e., if (very) high risks are assessed, additional measures may need to be taken by ships which are to be based on the G13 Guidelines (IMO, 2007b). In the Annex to the BWM Convention, Regulation A-4 provides an approach to issue exemptions from Regulation B-3 (Ballast Water Management for Ships) and also Regulation C-1 (Additional Measures) to address high risks (IMO, 2004).

IMO RA outlines three different RA methods, that is “environmental matching”, "species' biogeographical" and "species-specific" RA (IMO, 2017). Environmental matching RA between ballast water origin and discharge areas uses non-biological parameters as surrogates for the survival potential of species in the new environment. In the species’ biogeographical

\footnotetext{
${ }^{1}$ Ballast water management (BWM), Baltic Marine Environment Protection Commission (HELCOM), Convention for the Protection of the Marine Environment of the North-East Atlantic (OSPAR), Decision Support System (DSS), European Union (EU), Framework Programme (FP), harmful aquatic organisms and pathogens (HAOP), International Maritime Organization (IMO), Instrument for Pre-Accession Assistance (IPA), Joint Harmonised Procedure (JHP), risk assessment (RA), target species (TS), task group (TG).
} 
RA species are identified which have overlapping distribution in donor and recipient ports as well as biogeographic regions. Such an overlap is taken as direct similarity indication of the environmental conditions and hence the likeliness of species survival in the new environment. The species-specific RA considers the life history information and also physiological tolerances to identify the physiological limits of species. This is done to estimate the species potential to survive or to complete the entire life cycles in the new environment and this method considers target species (TS) (IMO, 2017). According to the G7 Guidelines the risk could be deemed to be high, e.g., if the species-specific RA identifies at least one TS that occurs in the donor port/area, but not in the recipient port, and that its survival is likely in the recipient port. Furthermore the G7 Guidelines specify that a priori criteria should be defined so that unacceptable high risk scenarios and acceptable low risk scenarios, where unmanaged ballast water is unlikely to damage or impair the environment, human health, property or resources of the port State or adjacent/other States, may be distinguished (IMO, 2017). It is therefore up to the port State granting the exemption, in consultation with other States that may be affected, to determine what constitutes an unacceptable risk.

According to IMO, TS are species that "meet specific criteria indicating that they may impair or damage the environment, human health, property or resources and are defined for a specific port, State or biogeographic region” (IMO, 2017). It should be noted that IMO does not distinguish between TS already introduced and those not yet introduced. According to the definition in the G7 Guidelines (IMO, 2017), at least all the following criteria have to be considered for the TS identification (David and Gollasch, 2018): (a) the relationship with ballast water as a transport vector, (b) the impact and its severeness, (c) the evidence of prior introduction(s), and (d) the current species distribution in its native biogeographic region and also in other biogeographic regions, as appropriate. 
In addition, several attempts were made to identify common biological characteristics of 'perfect' invasive species, which could be assumed as TS. In summary, a 'perfect' invasive species will show wide tolerances towards environmental factors and have high reproduction rates (Safriel and Ritte, 1980, 1983; Kareiva, 1999; Hewitt, 2003; Rewicz et al., 2014). These species should therefore also be considered as TS candidates in addition to the species which meet the IMO selection criteria, which do not address biological characteristics.

First considerations of TS in European Seas were conducted in 1999 (Gollasch and Leppäkoski, 1999) and this approach was updated in 2006 (Leppäkoski and Gollasch, 2006). These approaches were based on expert opinion and were prepared before the first G7 Guidelines were adopted at IMO in 2007 and are therefore considered as outdated. In 2013, HELCOM and OSPAR adopted the Joint HELCOM/OSPAR Guidelines to grant exemptions under the BWM Convention, Regulation A-4 (subsequently renamed JHP), which contain a list of TS for these regional seas in Annex 3 (HELCOM, 2013). More recently, the TS list was revised and endorsed by the Heads of Delegation of HELCOM (HELCOM, 2015a) and OSPAR in June 2015 (OSPAR, 2015a). The majority of the HELCOM countries are prepared to use this TS list, which contains 41 species, for the purpose of BWM exemptions according to the BWM Convention. The TS list is considered to be a living document (HELCOM, 2015b; OSPAR, 2015b) so that changes are to be expected as need arises.

The JHP is currently under a revision process which is expected to conclude during 20202021. As part of this process the TS selection criteria were amended and adopted in 2016 (HELCOM/OSPAR TG Ballast, 2016). Nevertheless, these criteria, like the G7 Guidelines, leave out a detailed description of the identification of TS. In the case of the G7 Guidelines, 
this may be due to the lack of knowledge and experience during the drafting phase of these guidelines. Now, more than a decade since the G7 Guidelines were adopted, several research projects addressed species-specific RA. Based on the review of current knowledge on the subject, detailed TS selection criteria have been identified within the ongoing EU-Interreg Baltic Sea Region project COMPLETE and are presented in this publication.

\section{Material and Methods}

The previously developed species-specific RA and TS literature, as indicated above, was revisited to evaluate their today's applicability to describe TS selection criteria. In addition, a comprehensive literature review was performed and the TS-related information in these documents was considered (see Table 1 for references ).

\begin{tabular}{|l|l|l|l|l|}
\hline Authors & Goals & RA approach & Data & expression \\
& & approach & End-point \\
\hline \hline
\end{tabular}




\begin{tabular}{|c|c|c|c|c|}
\hline Authors & Goals & RA approach & $\begin{array}{l}\text { Data } \\
\text { expression } \\
\text { approach }\end{array}$ & End-point \\
\hline $\begin{array}{l}\text { Hayes and } \\
\text { Hewitt, 1998; } \\
\text { Hayes, 2000; } \\
\text { Hewitt and } \\
\text { Hayes, 2002; } \\
\text { Hayes and } \\
\text { Sliwa, 2003; } \\
\text { Hewitt and } \\
\text { Campbell, 2007 }\end{array}$ & $\begin{array}{l}\text { Identification of } \\
\text { low risk routes, } \\
\text { vessels and tanks }\end{array}$ & $\begin{array}{l}\text { Four step bio-invasion } \\
\text { process: donor port } \\
\text { infection, vessel } \\
\text { infection, journey } \\
\text { survival and survival in } \\
\text { recipient port }\end{array}$ & Quantitative & $\begin{array}{l}\text { Completion of TS } \\
\text { life cycle in } \\
\text { recipient port }\end{array}$ \\
\hline $\begin{array}{l}\text { Gollasch and } \\
\text { Leppäkoski, } \\
1999\end{array}$ & $\begin{array}{l}\text { Risk identification } \\
\text { for Nordic ports } \\
\text { and coastal waters }\end{array}$ & $\begin{array}{l}\text { Environmental match } \\
\text { of donor and recipient } \\
\text { localities }\end{array}$ & Qualitative & $\begin{array}{l}\text { Species } \\
\text { establishment } \\
\text { potential } \\
\text { assessment, list of } \\
\text { TS }\end{array}$ \\
\hline $\begin{array}{l}\text { Behrens et al., } \\
\text { 2002; Endresen } \\
\text { et al., 2004; } \\
\text { Dragsund et al., } \\
2005\end{array}$ & $\begin{array}{l}\text { Identification of } \\
\text { low risk routes, } \\
\text { vessels and tanks }\end{array}$ & $\begin{array}{l}\text { Bioinvasion model } \\
\text { based upon: donor port } \\
\text { infection, vessel } \\
\text { infection, journey } \\
\text { survival and survival in } \\
\text { recipient port }\end{array}$ & Quantitative & $\begin{array}{l}\text { Completion of TS } \\
\text { life cycle in } \\
\text { recipient port }\end{array}$ \\
\hline
\end{tabular}




\begin{tabular}{|c|c|c|c|c|}
\hline Authors & Goals & RA approach & $\begin{array}{l}\text { Data } \\
\text { expression } \\
\text { approach }\end{array}$ & End-point \\
\hline $\begin{array}{l}\text { MacIsaac et al., } \\
2002\end{array}$ & $\begin{array}{l}\text { Evaluation of risk } \\
\text { with } \mathrm{NOBOB}^{2} \\
\text { vessels (Great } \\
\text { Lakes) }\end{array}$ & $\begin{array}{l}\text { Species tolerances and } \\
\text { propagule pressure of } \\
\text { NOBOB vessels }\end{array}$ & Quantitative & $\begin{array}{l}\text { Journey survival of } \\
\text { TS }\end{array}$ \\
\hline $\begin{array}{l}\text { GloBallast, } \\
\text { 2003; Awad et } \\
\text { al., } 2004\end{array}$ & $\begin{array}{l}\text { Awareness and } \\
\text { recommendations } \\
\text { on BWM strategies }\end{array}$ & $\begin{array}{l}\text { Environmental match } \\
\text { of donor and recipient } \\
\text { localities, weighted by } \\
\text { TS presence in the } \\
\text { donor location and } \\
\text { inoculation factors }\end{array}$ & $\begin{array}{l}\text { Semi- } \\
\text { quantitative }\end{array}$ & $\begin{array}{l}\text { Identification and } \\
\text { ranking of high and } \\
\text { low risk ports }\end{array}$ \\
\hline $\begin{array}{l}\text { MacIsaac et al., } \\
2004\end{array}$ & $\begin{array}{l}\text { Review and } \\
\text { development of a } \\
\text { ballast water RA }\end{array}$ & $\begin{array}{l}\text { TS (gravity model, i.e., } \\
\text { rates and pattern of } \\
\text { colonization) }\end{array}$ & Quantitative & $\begin{array}{l}\text { Colonization } \\
\text { prediction of TS }\end{array}$ \\
\hline $\begin{array}{l}\text { David, 2007; } \\
\text { David and } \\
\text { Gollasch, } 2016\end{array}$ & $\begin{array}{l}\text { Vessel-to-vessel } \\
\text { (tank) assessment } \\
\text { for BWM measures } \\
\text { supported by DSS }\end{array}$ & $\begin{array}{l}\text { Environmental match } \\
\text { of donor and recipient } \\
\text { localities (bioregions) } \\
\text { \& species-specific } \\
\text { (inside bioregion) }\end{array}$ & $\begin{array}{l}\text { Quantitative } \\
\text { \& qualitative }\end{array}$ & $\begin{array}{l}\text { Identification and } \\
\text { ranking of high and } \\
\text { low risk donor ports } \\
\text { \& identify high risk } \\
\text { species }\end{array}$ \\
\hline
\end{tabular}

${ }^{2} \mathrm{NOBOB}=$ no ballast on board 


\begin{tabular}{|c|c|c|c|c|}
\hline Authors & Goals & RA approach & $\begin{array}{l}\text { Data } \\
\text { expression } \\
\text { approach }\end{array}$ & End-point \\
\hline Heyer, 2012 & $\begin{array}{l}\text { Evaluation of } \\
\text { BWM exemptions } \\
\text { in North and Baltic } \\
\text { Seas }\end{array}$ & $\begin{array}{l}\text { TS and their } \\
\text { environmental } \\
\text { tolerance comparing } \\
\text { donor and recipient } \\
\text { port conditions }\end{array}$ & $\begin{array}{l}\text { Quantitative } \\
\text { \& qualitative }\end{array}$ & RA \\
\hline $\begin{array}{l}\text { Berggreen et } \\
\text { al., } 2013\end{array}$ & BWM exemptions & TS selection & Qualitative & RA \\
\hline $\begin{array}{l}\text { Puntila et al., } \\
2013\end{array}$ & $\begin{array}{l}\text { BWM exemption, } \\
\text { list of most } \\
\text { unwanted species }\end{array}$ & TS selection criteria & Qualitative & RA \\
\hline $\begin{array}{l}\text { David et al., } \\
2015\end{array}$ & BWM exemptions & $\begin{array}{l}\text { Environmental match } \\
\text { of donor and recipient } \\
\text { localities (bioregions) } \\
\text { \& species-specific } \\
\text { (inside bioregion) }\end{array}$ & $\begin{array}{l}\text { Quantitative } \\
\text { \& qualitative }\end{array}$ & RA \\
\hline Zenetos, 2015 & $\begin{array}{l}\text { Selection of most } \\
\text { impacting species }\end{array}$ & $\begin{array}{l}\text { Rapid assessment } \\
\text { surveys }\end{array}$ & Qualitative & High risk \\
\hline $\begin{array}{l}\text { Olenin et al., } \\
2016\end{array}$ & BWM exemptions & $\begin{array}{l}\text { Six major components } \\
\text { including TS selection } \\
\text { procedure }\end{array}$ & Qualitative & RA \\
\hline
\end{tabular}

Table 1. Chronological list of ballast water related RA initiatives addressing TS (enhanced and updated after David and Gollasch (2016)). 
Further, the BWM Convention and the G7 Guidelines together with JHP were studied with the RA-related work of previously completed EU-funded projects, i.e., the EU $7^{\text {th }}$ FP project VECTORS $^{3}$ (David and Gollasch, 2014) and the IPA-funded project BALMAS ${ }^{4}$ (David and Gollasch, 2016), to gather additional information regarding which TS selection criteria had been considered previously. During the ongoing EU-Interreg project COMPLETE all findings were re-considered and discussed.

\subsection{Terminology used}

The term HAOP is used in the BWM Convention. It is defined as "any aquatic organisms or pathogens, which, if introduced into the sea including estuaries, or into fresh water courses, may create hazards to the environment, human health, property or resources, impair biological diversity or interfere with other legitimate uses of such areas” (IMO, 2004). In consequence, HAOP include all potentially harmful non-indigenous and cryptogenic as well as impacting native aquatic species and pathogens (David et al., 2013; Gollasch et al., 2015). Impacting native aquatic species may include species causing harmful algal blooms, aquaculture pests, parasites and disease agents (Olenin et al., 2016). Therefore, and in line with the precautionary principle, all HAOP are potential TS (David et al., 2013; David and Gollasch, 2016).

\footnotetext{
${ }^{3}$ Vectors of Change in Oceans and Seas - Marine Life, Impact on Economic Sectors

${ }^{4}$ Ballast Water Management System for Adriatic Sea Protection
} 


\subsection{Additional guidance for TS selection criteria}

Considering the G7 Guidelines in detail (IMO, 2017), a questionnaire to identify TS was developed (Olenin et al., 2016). The content of this questionnaire was used as additional guidance to identify and describe the TS selection criteria. This questionnaire, which was based upon eleven questions and sub-questions, addressed mainly the relationship with ballast water, the basic ecology of the species and its impact on native species, the environment, human health and resource users. The answers to these questions were based upon scientific literature and expert knowledge to identify TS in selected ports.

\section{Results}

\subsection{Selection criteria of target species}

The TS selection criteria as described below are completely in line with the G7 Guidelines (IMO, 2017) and we also considered the TS selection approach as set out in the amended JHP for the Contracting Parties of OSPAR and HELCOM for granting BWM exemptions (HELCOM/OSPAR TG Ballast, 2016). It was noted that the G7 Guidelines TS identification criteria are more specific compared to JHP. According to JHP (HELCOM/OSPAR TG Ballast, 2016), two key questions should be addressed before a species is considered for TS list inclusion (a) "Is there a potential for a species to be primarily introduced or secondarily spread via ballast water or sediments as the major vector?", and (b) "Is the species present only in part(s) of the region but not the entire region in self-sustaining populations?”. In addition to these general aspects, "any impact" on human health, environment or economy 
identifies species for inclusion of the TS list. However, "any impact” is not further specified in the revised JHP TS selection criteria (HELCOM/OSPAR TG Ballast, 2016).

In the text that follows below, concrete and detailed TS selection criteria are described in order of importance based on current knowledge as well as the G7 Guidelines (IMO, 2017).

\subsubsection{Species relationship with ballast water as transport vector}

A positive species relationship with ballast water is given when it was previously found in a ballast tank or in cases when the species life cycle has a larval phase or planktonic adult as this makes a ballast water transport likely. In the many ballast water sampling studies conducted in the past living viruses, bacteria, human pathogens, fungi, protozoa, algae (unicellular phytoplankton algae and macroalgae), invertebrates and fish were found. The predominantly found species belonged to planktonic algae, crustaceans, molluscs and polychaetes. More than 1,000 species were identified in European ballast water studies. Most species were of small dimension so they withstand the physical forces of the vessel ballast water pumps during ballasting. However, some larger organisms were also found in ballast tanks, including decapods and fish with a body length up to $15 \mathrm{~cm}$ (Gollasch et al., 2002, 2015; AquaNIS. Editorial Board, 2015).

Many aquatic species life cycles include a planktonic or spreading phase and therefore all those species have a relationship with ballast water so that they could become TS. The spreading phase duration is neglected here as TS qualifier to implement the precautionary principle. This is because a shorter spreading phase does not disqualify a species from being 
TS in case of shorter vessel voyages, i.e., when the voyage is shorter than the spreading phase duration. The shortest spreading phase we are aware lasts only for minutes and this occurs during the development of the hydrocoral Allopora californica (Shanks, 2009). Other species have relatively short-lived spreading phases of a few hours up to a day with Didemnum spp. (Olson, 1983; Daley and Scavia, 2008; Gittenberger, 2010) and the sponge Sigmadocia caerulea being examples (Maldonado and Young, 1999). In contrast, long-lasting spreading phase durations of more than 200 days (Kempf, 1981) or up to a year were observed for several mollusks (Strathmann and Strathmann, 2007). As an example, in the Öresund (Baltic Sea) са. $63 \%$ of the species have long planktonic larvae, $6 \%$ short ( $<1$ week) planktonic larvae and 31\% develop without planktonic larvae (Thorson, 1946). Similar results were also found in a North American study (Grantham et al., 2003). In a study to compare larval durations of almost two hundred species of various higher taxonomic groups it was observed that for $80 \%$ of the species the larval duration is between a few days and six weeks (Tardent, 1979), which was also found by others (Shanks, 2009). Therefore, even spreading phase phases of a few hours do not guarantee that this species cannot be transported into the recipient port when the voyage is short or when reproduction inside a ballast tank is possible. Further, species may spread by fragmentation or form of resting stages, no matter how long the larval duration is, thereby surviving also longer vessel voyages. In conclusion, the only species not to be categorized as TS are only those which:

- lack a planktonic phase completely;

- live so deep in the sediment that they cannot be stirred up into the water column and be pumped into a ballast tank; or

- are in all developmental stages relatively large so that it is impossible that they pumped on board (e.g., larger fish, turtles). 


\subsubsection{Impact and its severeness}

Concerning the impact of species, it is suggested to differentiate within each impact category (human health, economy and environment) between acceptable and non-acceptable impact. Impact on health and measurable economic impact should always be considered as unacceptable. Accordingly, all human pathogens (more than limited in regulation D-2 of the BWM Convention, e.g., Streptococci, Staphylococci, Pseudomonas, Salmonella) and other species and/or strains than specified in D-2) and species with documented measurable economic impact are TS no matter the impact strength. The potential species environmental impact may be evaluated by applying impact categorization concepts (Olenin et al., 2007), which were also used in the BALMAS project (Garaventa et al., 2014; Magaletti et al., 2018). The biopollution assessment concept (Olenin et al., 2007) uses non-indigenous species (NIS) distribution information and abundance and includes an index which classifies impacts on native species, communities, habitats and ecosystem functioning. This concept enables assessments from being as low as the absence of any measurable impacts and it ends with high impacts as with major shifts or even catastrophic perturbations in the native community structure, habitat properties and ecosystem functioning (Olenin et al., 2007).

Based on the above mentioned differentiation, it is recommended that one threshold between acceptable and unacceptable impact based on their categorization is established (Olenin et al., 2007). This would also be in line with the recent JHP impact categories (HELCOM, 2015a). A low impact is characterized by (HELCOM, 2015a; Olenin et al., 2007): 
- "local displacement of native species, but no extinction. Change in ranking of native species, but dominant species remain the same. Type-specific communities are present $^{5}$;

- alteration of a habitat(s), but no reduction of spatial extent of a habitat(s) ${ }^{6}$;

- measurable, but weak changes with no loss or addition of new ecosystem function(s) ${ }^{7}$;

or

- measurable, but weak changes with no loss or addition of resources. ${ }^{8}$ ”

Species already in this impact category are seen as critical, and, following the precautionary principle, their introduction should be avoided. It is therefore suggested to define the threshold acceptable-unacceptable impact between the "No impact" and "Low impact" category (Table 2). This approach re-organizes some criteria formerly developed by Olenin et al. (2007) into now one category, i.e., unacceptable.

Regarding environmental impacts, these may occur at different levels (species, habitat, ecosystem functioning level). During BALMAS the impact on resource users was added to (a) complete the assessment concept of the impacts species may cause and to (b) fully reflect the IMO definition, i.e., impacting on the environment, human health, property or resources (David and Gollasch, 2016).

\footnotetext{
${ }^{5}$ One example is the non-indigenous barnacle Elminius modestus along the German North Sea coast. It overgrowths and occupies space so that it competes with other epifaunal species as, e.g., the native barnacle Balanus balanoides (Nehring 2005).

${ }^{6}$ The tube-building amphipod Chelicorophium curvispinum is one example to alter habitats, another example is the infaunal polychaete Marenzelleria neglecta due to its burrowing activity (Olenin and Leppäkoski, 1999; Kotta et al., 2001).

${ }^{7}$ No loss or addition of new ecosystem function may be observed following the occurrence of, e.g., a nonindigenous suspension feeder with the same function as native species. An example is the barnacle $E$. modestus along the German North Sea coast (Nehring, 2005).

${ }^{8}$ An example to demonstrate this impact is Antithamnionella ternifolia in the North Sea. It occurs scattered from France to Germany. In general it has a weak fouling impact. On Dutch oyster cultures it is found only on < $1 \%$ of the individuals (Isermann and Nehring 2017).
} 
Further, species where no impact information is available should be included to the TS list as a precautionary approach.

\begin{tabular}{|c|c|c|c|c|}
\hline $\begin{array}{l}\text { Impact } \\
\text { category }\end{array}$ & Impact on species & $\begin{array}{l}\text { Impact on } \\
\text { habitat }\end{array}$ & $\begin{array}{l}\text { Impact on eco- } \\
\text { system } \\
\text { functioning }\end{array}$ & $\begin{array}{l}\text { Impact on } \\
\text { resource users }\end{array}$ \\
\hline Acceptable & $\begin{array}{l}\text { No displacement of } \\
\text { native species, although } \\
\text { NIS may be present. } \\
\text { Status of native species } \\
\text { according to } \\
\text { quantitative parameters } \\
\text { in the community } \\
\text { remains unchanged }\end{array}$ & $\begin{array}{l}\text { No habitat } \\
\text { alteration }\end{array}$ & $\begin{array}{l}\text { No measurable } \\
\text { effect }\end{array}$ & $\begin{array}{l}\text { No measurable } \\
\text { effect }\end{array}$ \\
\hline \multicolumn{5}{|c|}{ THRESHOLD } \\
\hline Unacceptable & $\begin{array}{l}\text { Local displacement of } \\
\text { native species, but no } \\
\text { extinction. Change in } \\
\text { ranking of native } \\
\text { species, but dominant } \\
\text { species remain the } \\
\text { same. Type-specific } \\
\text { communities are }\end{array}$ & $\begin{array}{l}\text { Alteration } \\
\text { of a } \\
\text { habitat(s), } \\
\text { but no } \\
\text { reduction of } \\
\text { spatial } \\
\text { extent of a } \\
\text { habitat(s) }\end{array}$ & $\begin{array}{l}\text { Measurable, but } \\
\text { weak changes } \\
\text { with no loss or } \\
\text { addition of new } \\
\text { ecosystem } \\
\text { function(s) }\end{array}$ & $\begin{array}{l}\text { Measurable, } \\
\text { but weak } \\
\text { changes with } \\
\text { no loss or } \\
\text { addition of } \\
\text { resources }\end{array}$ \\
\hline
\end{tabular}




\begin{tabular}{|c|c|c|c|c|}
\hline $\begin{array}{l}\text { Impact } \\
\text { category }\end{array}$ & Impact on species & $\begin{array}{l}\text { Impact on } \\
\text { habitat }\end{array}$ & $\begin{array}{l}\text { Impact on eco- } \\
\text { system } \\
\text { functioning }\end{array}$ & $\begin{array}{l}\text { Impact on } \\
\text { resource users }\end{array}$ \\
\hline & present & & & \\
\hline & $\begin{array}{l}\text { Large scale } \\
\text { displacement of native } \\
\text { species causes decline } \\
\text { in abundance and } \\
\text { reduction of their } \\
\text { distribution range } \\
\text { within the assessment } \\
\text { unit; and/or type- } \\
\text { specific communities } \\
\text { are changed noticeably } \\
\text { due to shifts in } \\
\text { community dominant } \\
\text { species }\end{array}$ & $\begin{array}{l}\text { Alteration } \\
\text { and } \\
\text { reduction of } \\
\text { spatial } \\
\text { extent of a } \\
\text { habitat(s) }\end{array}$ & $\begin{array}{l}\text { Moderate } \\
\text { modification of } \\
\text { ecosystem } \\
\text { performance } \\
\text { and/or addition of } \\
\text { a new, or } \\
\text { reduction of } \\
\text { existing, } \\
\text { functional } \\
\text { group(s) in part of } \\
\text { the assessment } \\
\text { unit }\end{array}$ & $\begin{array}{l}\text { Moderate } \\
\text { modification } \\
\text { of resources } \\
\text { and/or addition } \\
\text { of a new, or } \\
\text { reduction of } \\
\text { existing, } \\
\text { resources in } \\
\text { part of the } \\
\text { assessment } \\
\text { unit }\end{array}$ \\
\hline & $\begin{array}{l}\text { Population extinctions } \\
\text { within the ecosystem. } \\
\text { Former community } \\
\text { dominant species still } \\
\text { present but their } \\
\text { relative abundance is } \\
\text { severely reduced; NIS } \\
\text { are dominant. Loss of }\end{array}$ & $\begin{array}{l}\text { Alteration } \\
\text { or loss of } \\
\text { habitat(s), } \\
\text { severe } \\
\text { reduction of } \\
\text { spatial } \\
\text { extent of } \\
\text { habitat(s) }\end{array}$ & $\begin{array}{l}\text { Severe shifts in } \\
\text { ecosystem } \\
\text { functioning. } \\
\text { Reorganisation of } \\
\text { the food web as a } \\
\text { result of addition } \\
\text { or reduction of } \\
\text { functional groups }\end{array}$ & $\begin{array}{l}\text { Severe shifts in } \\
\text { resources with } \\
\text { income loss for } \\
\text { resource users }\end{array}$ \\
\hline
\end{tabular}




\begin{tabular}{|l|l|l|l|l|}
\hline Impact & Impact on species & Impact on & Impact on eco- & Impact on \\
habitat & system & resource users \\
& fynctioning & within trophic & \\
& community within an & & levels & \\
\hline
\end{tabular}

Table 2. HAOP environmental impact categories (modified after Olenin et al. (2007)).

\subsubsection{Evidence of prior introduction(s)}

When all HAOP of the donor port/area are considered, species which are documented as to be introduced to areas outside of their native ranges are potential TS as their ability to spread is self-evident.

\subsubsection{Current distribution}

An assessment to determine whether a HAOP is present in the donor port/area but not in the recipient port may be carried out. However, this has to be based upon port baseline sampling surveys due to the reliable data requirement (HELCOM, 2013; HELCOM/OSPAR TG Ballast, 2016; IMO, 2017). In addition, the distribution of HAOP in their native and other biogeographic regions has to be evaluated. Consequently, a wide biogeographical or habitat 
distribution makes a species to be considered as potential TS. Further, species known as HAOP in other biogeographic regions are also considered as potential TS.

The current species distribution has an influence on the species impacts. By simple logic, only species with a wide distribution may result in the highest category of impact. This means that, e.g., only widely distributed species may cause large-scale displacements or extinctions of other species. Nevertheless, a small-scale distributed species with local impact may be of unacceptable consequence should it overlap in distribution with a rare or endangered species, especially when this has a restricted distribution. In such a case, even a HAOP with a limited distribution may be responsible for a strong impact as it may lead to an extinction of a rare or endangered species.

Further, locally distributed species may result in a strong resource user's impact. One example is the fouling species Ficopomatus enigmaticus which during mass developments clogged industrial water pipes in a small area in the Port of Emden (Germany), which was enabled by elevated water temperatures due to discharges of heated power plant effluents (Kühl, 1977). After some time of adaptation it spread further increasing its distribution area and consequently it caused a stronger impact.

\section{Discussion}

One of the difficulties in identifying TS is the possible subjectivity in their selection process. Without clear guidance it is possible that the assessment if a species should become a TS or not exhibits a degree of uncertainty, i.e., species identified as harmful in some areas may not 
be harmful in others or vice versa (David et al., 2013). As a consequence, species may be considered as TS in one region but not elsewhere. Also, different experts in one region may evaluate the identical species as TS or not. To overcome this problem, the above outlined TS selection criteria were developed.

Despite best efforts, several challenges remain and these include that native species in one region may become invasive when they were transported to another region. Further, an introduced species of no concern (a non-TS) in a donor port/area may become invasive when transported elsewhere (Carlton and Geller, 1993).

It was further concluded that a species, that has been included in a control or in an eradication program in any ballast water donor port/area will become TS. It is therefore recommended to consider these species with priority. The reasoning is that in case others try to control or eradicate a species it is because of its strong negative impact, and a recipient port will not agree to receive unmanaged ballast water from a donor port/area where such species occurs. However, this is seen as additional information as it will be impossible to evaluate for all species found during a port survey whether they underwent a control or eradication program elsewhere. In contrast, should a species control or eradication programme be ongoing in the recipient port, a re-introduction of individuals of that species would be seen as an undesirable event thus these species become TS. This important point is frequently overlooked.

The above-mentioned TS selection criteria are partly connected with each other and therefore have to be assessed in a step-by-step process. For example, a strongly negatively impacting species, which has no larval or spreading phase, will not be seen as TS as it cannot be 
transported by ballast water. As another example, a wide spread species, which occurs in low numbers may cause no impact and is therefore not seen as TS.

We conclude that a step-wise approach to evaluate whether or not species are considered TS is needed:

Step 1 - List all species found during the current JHP port baseline surveys (and if available additional data from other surveys) of both/all ports involved under consideration for BWM exemptions.

Step 2 - Compare species sampled during JHP port baseline surveys with all species on the existing HELCOM/OSPAR TS list. Any matching species found in the ports to be considered, are identified as TS.

Step 3 - For the remaining species, additional TS should be selected using the criteria which identify those species which have the ability to invade and become harmful. At least all following criteria need to be considered when identifying TS:

1. relationship with the transport vector ballast water, i.e., species which were already found in ballast tanks or which includes a larval phase or planktonic adult to make a ballast water transport likely. Species unknown to be ballast water related cannot become a TS in this context;

2. impact and its severeness, i.e.; does the species cause a measurable impact? It was agreed that the impact to human health (pathogens) should be prioritized, followed by economic impact, followed by environmental impact. In this sense all human 
pathogens and species with an economic impact are TS no matter how strong the impact is. Only for environmentally impacting species the impact severeness is assessed. Only species assessed as with higher than low impact are considered as TS. The species assessed as with low impact would also be categorized as TS when expert opinion reveals that impacts may be increasing;

3. evidence of earlier introduction(s) elsewhere, i.e., the species ability was documented that it became introduced outside its native area. The evidence of prior introduction gives an indication on the potential of the species to spread. Once a species has shown its potential to spread it becomes a potential TS. However, no evidence of prior introduction gives no guarantee that the species may not be introduced to the concerned port(s). Please note that the spreading potential of the species may change according to the changes in the port environments; and

4. current distribution in its native biogeographic and in other biogeographic regions has to be evaluated. Species with a wide biogeographical or habitat distribution or species which are invasive elsewhere, are categorized as potential TS.

Step 4 - Prepare a list of all TS in both/all ports. It is recommended conducting this in a transparent format, i.e., develop a species evaluation sheet that the reader can see which criterion applies to a certain species and which not. This may be done in table format including references when available.

The existing HELCOM/OSPAR TS lists need to be reviewed. In the past the TS selection criteria were not clearly formulated and some species came on the list purely because of expert opinion. Only those species that meet the criteria as listed above should remain on this list. It was recommended that the new HELCOM TS list may transparently be developed, i.e., 
as a list where the criterion/criteria to identify TS are clearly attributed to individual species on the list.

It is further recommended that the here described and explained TS selection criteria may be adopted in other activities when planning species-specific RA for exemptions from BWM requirements, e.g., when considering the Same Risk Area concept as defined the G7 Guidelines (IMO, 2017).

\section{Acknowledgements}

This study was prepared within the project COMPLETE - Completing management options in the Baltic Sea region to reduce risk of invasive species introduction by shipping. This work was supported by the European Union's funding Programme Interreg Baltic Sea Region (European Regional Development Fund).

\section{References}

AquaNIS. Editorial Board, 2015. Information system on Aquatic Non-Indigenous and Cryptogenic Species. World Wide Web electronic publication. www.corpi.ku.lt/databases/aquanis. Version 2.36+. Accessed 2018-11-23.

Awad A., Clarke C., Greyling L., Hilliard R., Polglaze T., Raaymakers S., 2004. Ballast Water Risk Assessment, Port of Saldanha Bay, Republic of South Africa, November 2003: Final Report. GloBallast Monograph Series No. 13. IMO, London. 
Behrens H.L., Haugom G.P., Mordal Bakke S., 2002. EMBLA Concept; Risk assessment methodology and impact and consequence methodology scheme. DNV Rep. No. 20021269.

Berggreen U.C., Nygaard Hvid H., Uldal C., Jensen K.R., 2013. Target Species, risk assessment - Ports and Ballast Water. Selection of Target Species for Risk Assessment of Danish Ports in Connection with the International Convention for the Control and Management of Ships' Ballast Water and Sediments. ISBN nr. 978-87-7091-626-4. Miljøministeriet. Naturstyrelsen, Copenhagen.

Carlton J.T., Geller J.B., 1993. Ecological roulette: the global transport of non-indigenous marine organisms. Science 261:78-82.

Daley, B.A., Scavia, D., 2008. An integrated assessment of the continued spread and potential impacts of the colonial ascidian, Didemnum sp. A, in U.S. waters. NOAA Technical Memorandum NOS NCCOS 78: 61 pp.

David M., 2007. A decision support system model for ballast water management of vessels: doctoral dissertation. University of Ljubljana, Portorož.

David M., Gollasch S., (in press). Risk assessment for ballast water management - learning from the Adriatic Sea case study. Marine Pollution Bulletin, Special Issue.

David M., Gollasch S., 2014. Review of ballast water discharge risk assessment tools, and new decision support systems for EU ports to avoid aquatic species invasions. Deliverable No: 6.3. EU-funded project Vectors of Change in Oceans and Seas Marine Life, Impact on Economic Sectors (VECTORS), European Community's Seventh Framework Programme (FP7/2007-2013), Grant Agreement No. [266445]. 285 pp.

David M., Gollasch S., 2016. Risk assessment decision support system models for ballast water management purposes in the Adriatic - RA DSS, including reviews, models and 
test results of RA DSS on different scenarios that may occur in shipping in the Adriatic. Final Report, BALMAS project. 75 pp.

David M., Gollasch S., 2018. How to approach ballast water management in European seas. Estuarine, Coastal and Shelf Science 201, 248-255. http://dx.doi.org/10.1016/j.ecss.2016.10.018.

David M., Gollasch S., Leppäkoski E., 2013. Risk assessment for exemptions from ballast water management - The Baltic Sea case study. Marine Pollution Bulletin 75, 205-217. http://dx.doi.org/10.1016/j.marpolbul.2013.07.031,

David M., Gollasch S., Leppäkoski E., Hewitt C., 2015. Risk assessment in ballast water management. In David M, Gollasch S (eds) Global Maritime Transport and Ballast Water Management - Issues and Solutions. Invading Nature. Springer Series in Invasion Ecology 8, Springer Science + Business Media, Dordrecht, The Netherlands. 306 pp.

Dragsund E., Andersen A.B., Gollasch S., ten Hallers-Tjabbes C.C., Skogen K., 2005. Ballast Water Scoping Study. Det Norske Veritas, Report 2005-0638, Hövik.

Endresen Ø., Behrens H.L., Brynestad S., Andersen A.B., Skjong R., 2004. Challenges in global ballast water management. Mar Poll Bull 48, 615-623. doi:10.1016/j.marpolbul.2004.01.016.

Garaventa F., Magaletti E., Castriota L., Silvestri C., Tornambè A., Falautano M., Maggio T., Gollasch S., Muha T.P., Mozetič P., Pigozzi S., David M., 2014. Review and comment general categorization criteria and selection of a promising EWS approach for the Adriatic. Report. BALMAS project. WP 6.3. 16 pp.

Gittenberger, A., 2010. Risk analysis of the colonial sea-squirt Didemnum vexillum Kott, 2002 in the Dutch Wadden Sea, a UNESCO World Heritage Site. The Invasive Alien 
Species Team of the Dutch Ministry of Agriculture, Nature \& Food Quality, Wageningen, The Netherlands. 32 pp.

GloBallast, 2003. Ballast Water Risk Assessment, User guide for the ballast water risk assessment database/GIS System. GEF/UNDP/IMO, Global Ballast Water Management Program. URS Meridian-GIS. International Maritime Organization, London.

Gollasch S., Leppäkoski E., 1999. Initial risk assessment of alien species in Nordic coastal waters. Nord 1999: 8. Nordic Council of Ministers, Copenhagen. 244 pp.

Gollasch S., Macdonald E., Belson S., Botnen H., Christensen J., Hamer J., Houvenaghel G., Jelmert A., Lucas I., Masson D., McCollin T., Olenin S., Persson A., Wallentinus I., Wetsteyn B., Wittling T., 2002. Life in ballast tanks. In: Leppäkoski E, Gollasch S, Olenin S (eds) Invasive aquatic species of Europe: distribution, impacts and management. Kluwer Academic Publishers, Dordrecht, pp 217-231.

Gollasch S., Minchin, D., David M., 2015. The Transfer of Harmful Aquatic Organisms and Pathogens with Ballast Water and their Impacts. In David M, Gollasch S (eds) Global Maritime Transport and Ballast Water Management - Issues and Solutions. Invading Nature. Springer Series in Invasion Ecology 8, Springer Science + Business Media, Dordrecht, The Netherlands. 306 pp.

Grantham B.A., Eckert G.L., Shanks A.L., 2003. Dispersal potential of marine invertebrates in diverse habitats. Ecological Applications 13(1) Supplement, 108-116.

Hayes K.R., 2000. Quantitative ecological risk assessment, a ballast water case study. PhD thesis.

Hayes K.R., Hewitt C.L., 1998. A risk assessment framework for ballast water introductions. CRIMP Technical Report 14, Division of Marine Research, CSIRO, Hobart. Hayes K.R., Sliwa C., 2003. Identifying potential marine pests - a deductive approach applied to Australia. Mar Poll Bull 46, 91-98. 
HELCOM, 2013. Joint HELCOM/OSPAR Guidelines on the granting of exemptions under the International Convention for the Control and Management of Ships' Ballast Water and Sediments, Regulation A-4, document adopted as part of the 2013 HELCOM Ministerial Declaration.

HELCOM, 2015a. Revised Target Species List for BWMC A-4 exemptions in the Baltic. Baltic Marine Environment Protection Commission (HELCOM), Heads of Delegation Meeting, Tallinn, Estonia, 10-11 June 2015 (HOD 48-2015), document 3-20.

HELCOM, 2015b. Outcome of the $48^{\text {th }}$ meeting of Heads of Delegation (HELCOM HOD). Baltic Marine Environment Protection Commission (HELCOM), Heads of Delegation Meeting, Tallinn, Estonia, 10-11 June 2015 (HOD 48-2015).

HELCOM/OSPAR TG BALLAST, 2016. Annex 3 of the Outcome of the Seventh Meeting of the Joint HELCOM/OSPAR Task Group on Ballast Water Management Convention Exemptions, Brussels, Belgium, 29-30 November 2016.

Hewitt C.L., 2003. Marine biosecurity issues in the world oceans: global activities and Australian directions. Ocean Yearb. 17, 193-212.

Hewitt C.L., Campbell M.L., 2007. Mechanisms for the prevention of marine bioinvasions for better biosecurity. Marine Pollution Bulletin 55, 395-401. doi:10.1016/j.marpolbul.2007.01.005.

Hewitt C.L., Hayes K.R., 2002. Risk Assessment of Marine Biological Invasions. In: Leppäkoski, E., Gollasch, S., Olenin, S. (Eds.), Invasive Aquatic Species of Europe Distribution, Impact and Management. Kluwer Academic Publishers, Dordrecht, The Netherlands, pp. 456-466.

Heyer K., 2012. Compiling and testing of biological risk assessments for the invasion of alien species with ballast water. HELCOM MARITIME 11/2012, Maritime Group Eleventh Meeting, 6-8 November 2012. Helsinki Commission, Copenhagen. 
IMO, 2004. International convention for the control and management of ships' ballast water and sediments, 2004. International Maritime Organization, 13 Feb 2004, London.

IMO, 2007a. Guidelines for risk assessment under regulation A-4 of the BWM Convention (G7). Marine Environment Protection Committee, Resolution MEPC.162(56), 13 Jul 2007. International Maritime Organization, London.

IMO, 2007b. Guidelines for additional measures regarding ballast water management including emergency situations (G13). Marine Environment Protection Committee, Resolution MEPC.161(56), 13 Jul 2007. International Maritime Organization, London.

IMO, 2017. 2017 Guidelines for risk assessment under regulation A-4 of the BWM Convention (G7). Marine Environment Protection Committee, Resolution MEPC.289(71), 7 Jul 2017. International Maritime Organization, London.

Isermann M., Nehring, S. 2017. Antithamnionella ternifolia. In: Rabitsch W, Nehring S. (eds). Naturschutzfachliche Invasivitätsbewertungen für in Deutschland wild lebende gebietsfremde aquatische Pilze, Niedere Pflanzen und wirbellose Tiere. Ergebnisse aus dem F+E-Vorhaben FKZ 351486 0200. BfN-Skripten 458, Bundesamt für Naturschutz, Bonn, Germany. 220 pp. (and references therein).

Kareiva P., 1999. Developing a predictive ecology for non-indigenous species and ecological invasions. Ecology 77, 1651-1652.

Kempf S.C., 1981. Long-lived larvae of the gastropod Aplysia juliana: Do they disperse and metamorphose or jst slowly fade away? Mar. Ecol. Prog. Ser. 6, 61-65.

Kotta J., Orav H., Sandberg-Kilpi E., 2001. Ecological consequence of the introduction of the polychaete Marenzelleria cf. viridis into a shallow-water biotope of the northern Baltic Sea. Journal of Sea Research 46, 273-280.

Kühl H., 1977. Mercierella enigmatica (Polychaeta: Serpulidae) an der deutschen Nordseeküste. Veröff. Inst. Meeresforsch. Bremerh. 16, 99-104. 
Leppäkoski L., Gollasch S., 2006. Risk Assessment of Ballast Water Mediated Species Introductions - a Baltic Sea Approach. Report prepared for HELCOM, Helsinki, Finland. 111 pp.

MacIsaac H.J., Borbely J.V.M., Muirhead J.R., Graniero P., 2004 Backcasting and forecasting biological invasions of inland lakes. Ecol Appl 14(3), 773-783.

MacIsaac H.J., Robbins T.C., Lewis M.A., 2002. Modeling ships’ ballast water as invasion threats to the Great Lakes. Can J Fish Aquat Sci 59, 1245-1256. DOI: 10.1139/F02090.

Magaletti E., Garaventa F., David M., Castriota L., Kraus R., Luna Gian M., Silvestri C., Forte C., Bastianini M., Falautano M., Maggio T., Rak G., Gollasch S., 2018. Developing and testing an Early Warning System for Non Indigenous Species and Ballast Water Management. J Sea Res 123 (Special Issue Ballast Water Management), 100-111. http://dx.doi.org/10.1016/j.seares.2017.03.016.

Maldonado M., Young C.M., 1999. Effects of the duration of larval life on postlarval stages of the demosponge Sigmadocia caerulea. Journal of Experimental Marine Biology and Ecology 232, 9-21.

Nehring S., 2005. International shipping - a risk for aquatic biodiversity in Germany. In: Nentwig, W. (Ed.), Biological Invasions - From Ecology to Control. Neobiota 6, 125144.

Olenin S., Leppäkoski E., 1999. Non-native animals in the Baltic Sea: alteration of benthic habitats in coastal inlets and lagoons. Hydrobiologia 393, 233-243.

Olenin S., Minchin D., Daunys D., 2007. Assessment of biopollution in aquatic ecosystems. Marine Pollution Bulletin 55, 379-394. doi:10.1016/j.marpolbul.2007.01.010. 
Olenin S., Ojaveer H., Minchin D., Boelens R., 2016. Assessing exemptions under the ballast water management convention: preclude the Trojan horse. Marine Pollution Bulletin 103, 84-92. http://dx.doi.org/10.1016/j.marpolbul.2015.12.043.

Olson R.R., 1983. Ascidian-Prochloron symbiosis: the role of larval photoadaptations in midday larval release and settlement. Biological Bulletin 165, 221-240.

OSPAR, 2015a. Meeting of the OSPAR Commission (OSPAR), Belgium, Ostend, 22-26 June 2015, Summary Record, Document 15/20/E-1.

OSPAR, 2015b. OSPAR Target Species List (OSPAR Agreement 2015-01).

Puntila R., Heyer K., Stelzer K., Faber E., 2013. Study on Biological Survey Protocols and Target Species Selection (HELCOM ALIENS 2). Final Report, HELCOM, Helsinki. 34 pp.

Rewicz T., Grabowski M., MacNeil C., Bącela-Spychalska K., 2014. The profile of a 'perfect' invader - the case of killer shrimp, Dikerogammarus villosus. Aquatic Invasions 9(3), 267-288. http://dx.doi.org/10.3391/ai.2014.9.3.04.

Safriel U.N., Ritte U., 1980. Criteria for the identification of potential colonizers. Biol J Linn Soc 13:287-297.

Safriel U.N., Ritte U., 1983. Universal correlates of colonizing ability. In: Swingland IR, Greenwood PJ (eds) The ecology of animal movement. Clarendon, Oxford, 215-239.

Shanks A.L., 2009. Pelagic larval duration and dispersal distance revisited. Biological Bulletin 216, 373-385.

Strathmann M.F., Strathmann R.R., 2007. An Extraordinarily Long Larval Duration of 4.5 Years from Hatching to Metamorphosis for Teleplanic Veligers of Fusitriton oregonensis. Biol. Bull. 213, 152-159.

Tardent P., 1979. Meeresbiologie. Eine Einführung: Georg Thieme Verlag, Stittgart, Germany. 381 pp. 
Thorson G., 1946. Reproduction and development of Danish marine bottom invertebrates, with special reference to the planktonic larvae in the sound (Øresund). Meddelelser fra Kommissionen for Danmarks Fiskeri-og Havundersøgelser, Serie Plankton 4, 1-523.

Zenetos A. (ed.), 2015. Illustrated Guide of Marine Alien species in the Mediterranean for Students and Citizen Scientis ts. COST1209 Action: Alien Challenge, 22pp. 